\title{
THE EFFICIENCY OF REGIONAL GOVERNMENT EXPENDITURE IN SMART TOURIST DESTINATION: THE CASE OF CROATIA
}

\author{
Sabina Hodžić \\ Dubravka Jurlina Alibegović
}

https://doi.org/10.20867/tosee.05.35

\begin{abstract}
Purpose -Regional and local governments have recognized the importance of tourism for the regional economy, especially when it comes to budget revenues and expenditures. Efficiency is crucial for making sure beneficiaries receive the best-possible services in a given tourist destination. Therefore, the aim of this paper is to analyze the efficiency of regional government expenditures in 20 Croatian counties in the 2011-2016 period.

Methodology - A data envelopment analysis (DEA) was applied to analyze the efficiency of regional government expenditures in smart tourist destinations. This is a non-parametric linear programming method for assessing the efficiency and productivity of decision-making units. For the purpose of this empirical investigation, 20 Croatian counties were observed, along with their average budget expenditures, in the 2011-2016 period.

Findings - The results of the empirical analysis showed that there are an equal number of coastal and inland Croatian counties when it comes to regional government expenditure efficiency. This is interesting to mention, since more international tourists are gravitating towards smart tourist destinations located on the Croatian coastline, especially in the summer season. The results may provide regional and local governments with more information on the concept of "smartness" when it comes to tourist destinations, and their potential for sustainable development and economic growth.

Contribution - This paper provides an empirical analysis on the efficiency of regional government expenditures in 20 Croatian counties in the 2011-2016 period. Its theoretical contribution consists of presenting the "smartness" concept and its importance for tourist destinations.

Keywords expenditures, regional government, data envelopment analysis, smart tourism destination, Croatia
\end{abstract}

\section{INTRODUCTION}

In today's world the public sector recognizes the potential of smartness for the environment and its importance for economic growth. Therefore, local and regional development play an important role. For their development the main determinants are financial resources within the budget, technology and concept of smartness. Moreover, cities like Barcelona and Amsterdam have incorporated the concept of smartness into their policies and strategies to achieve sustainable development and economic growth. In addition, Amsterdam has become a pioneer in the smart city movement, where successful results are linked to strategic urban planning principles (Mora and Bolici, 2017). For the tourism sector, a smart tourism destination is an important element. In addition, a smart tourism destination is an extension idea of smart cities to include 
ToSEE - Tourism in Southern and Eastern Europe, Vol. 5, pp. 307-318, 2019

S. Hodžić, D. Jurlina Alibegović: THE EFFICIENCY OF REGIONAL GOVERNMENT EXPENDITURE ...

tourism areas. This is linked to tourism destination management and e-destinations. The main characteristic of a smart tourism destination is the use of information and communications technologies in order to improve the capabilities of a destination. This affects the needs of tourists, and tourism companies need to provide quick responses. Besides that, the collaboration and cooperation of private and public organizations as well as regional and local government is a required characteristic for a smart tourism destination. Therefore, the governance of a smart tourism destination should be very sophisticated in order to encourage and regulate the multiple relationships between the diverse actors and users of its system. Moreover, the efficiency of regional government expenditures plays a key role. By providing more funds from the regional government budget to ensure advanced information technology within the tourism industry, the regional and local community and visitors of the tourist destination benefit.

The aim of this paper is to analyze the efficiency of regional government expenditures for tourism in 20 Croatian counties (Zagreb, Krapina-Zagorje, Sisak-Moslavina, Karlovac, Varazdin, Koprivnica-Krizevci, Bjelovar-Bilogora, Primorje-Gorski Kotar, Lika-Senj, Virovitica-Podravina, Pozega-Slavonija, Brod-Posavina, Zadar, OsijekBaranja, Sibenik-Knin, Vukovar-Sirmium, Split-Dalmatia, Istria, Dubrovnik-Neretva, and Medimurje) in the period 2011-2016. The City of Zagreb was excluded from the analysis due to its dual status as both a city and county. To obtain the empirical analysis, two input variables (expenditures for tourism and expenditures for recreation, culture and religion for each county) and two output variables (total tourist arrivals and total tourist nights for each county) were taken into consideration. In addition, this paper contributes to the research evidence on different regional government expenditure efficiency for tourism among Croatian counties in the average period 2011-2016. Therefore, the concept of smartness and its importance for a tourist destination is also presented.

The paper is organized as follows. After the introduction, Section 1 provides a brief literature review of smart tourism destinations and the efficiency of regional and local government expenditures. In Section 2 the data and methodology are described, while Section 3 presents the empirical results. In the conclusion, concluding remarks and recommendations for further research are presented.

\section{LITERATURE REVIEW}

Tourism is a complex phenomenon which includes all relevant factors, such as data, information and knowledge from and about tourists, innovations, public and regional financial support from governments and others. In addition, if smart devices, social media and mobile technologies are included within a tourist destination, then we are talking about a smart tourism destination. Since the main goal is to achieve a smart experience connected with information and communication technologies, there is also a problem with the efficiency of tourism expenditures. There are numerous studies which have researched the concept of smart tourism destinations and the expenditure efficiency of local governments. 
ToSEE - Tourism in Southern and Eastern Europe, Vol. 5, pp. 307-318, 2019

S. Hodžić, D. Jurlina Alibegović: THE EFFICIENCY OF REGIONAL GOVERNMENT EXPENDITURE ...

Buhalis and Amaranggana (2014) define a smart tourism destination as the "result of the interconnection of tourism destinations with multiple community stakeholders through dynamic platforms, knowledge intensive communication flows and enhanced decision support systems" (p. 557). The ultimate goal is to achieve a smart experience by maximizing both the destination's competitiveness and consumers' satisfaction, with attention paid to sustainability over an extended period. Based on the research of Boes et al. (2015), the information and communication technology is used to enable the cocreation of value and experiences for tourists as well as to create wealth, profits and other benefits for the organizations and destinations. Therefore, a smart tourism destination is an area where different research perspectives in terms of models, tools and strategies are inevitable in order to sustain the process of intelligent configuration of destinations (Shapiro, 2006; Buhalis and Law, 2008; Hollands, 2008; Sigala et al. 2012; Albino et al. 2015; Neirotti et al. 2016; Del Vecchio et al. 2018). In addition, the concept and potential of smartness have started to be recognized by the regional and local governments and the public sector. This concept is causing a paradigm shift within the tourism industry, especially for smart tourism destinations. The main characteristics of a smart tourism destination are presented in Table 1 (see Appendix). According to Boes et al. (2016), the concept of smartness consists of information and communication technologies, leadership, innovation and social capital supported by human capital. Moreover, this will increase the efficiency of processes and public financial resources in order to develop the competitive advantage of a smart tourism destination. This is in line with the economic theory that the majority of public resources in regional and local budgets is spent on providing a range of public services, like education, health care, tourism and others.

Upon observing only, the studies regarding public sector efficiency, there are quite a number of different comparisons within different public sector services. Among all of them, we found that they all use a data envelopment analysis (DEA) to measure the efficiency. This is an important element in the optimal use of resources whose aim is to ensure the provision of public goods and services. This is essential in order to ensure that beneficiaries receive the best services possible. O'Sullivan and Sheffrin (2003) found that, "one economic system is more efficient than the next when it offers a bigger supply of public goods and services without consuming a higher amount of resources" (p.13 18). Regarding the public sector services, Afonso and Aubyn (2004) examined the efficiency of expenditures in the education and health sectors based on a sample of OECD countries. To obtain empirical results, they applied two non-parametric methodologies - a data envelopment analysis and free disposal hull. The sector of education was investigated by De Borger and Naper (2006). They found that a high level of municipal revenues, a high degree of party fragmentation and a high share of socialists are associated with low education efficiency in secondary schools in Norway. In Croatia, only a few researchers have examined the efficiency of public spending in local governments (Jurlina Alibegovic and Blazevic, 2010; Bejakovic et al., 2011; Jurlina Alibegovic and Slijepcevic, 2012; Hodžić et al., 2017). In the tourism industry, the pioneers that implemented the DEA analysis at the micro level were Banker and Morey (1986). In their research they measured technical and scale efficiency of 60 restaurants of a fast food chain by using six input and three output variables. At the micro level, the hotel sector was examined by Johns et al. (1997), Anderson et al. (2000), Hwang and Chang (2003), Barros and Alves (2004) and Barros and Mascarenhas (2005). The 
ToSEE - Tourism in Southern and Eastern Europe, Vol. 5, pp. 307-318, 2019

S. Hodžić, D. Jurlina Alibegović: THE EFFICIENCY OF REGIONAL GOVERNMENT EXPENDITURE ...

efficiency of the tourism industry at the macro level was examined by Peypoch (2007), Barros et al. (2011), Hadad et al. (2012), and Soysal-Kurt (2017). Based on all previous research, our research makes an additional scientific contribution by adding new empirical evidence on regional government expenditure efficiency in Croatian counties.

\section{DATA AND METHODOLOGY}

In order to obtain empirical results, the regional government expenditure efficiency of 20 Croatian counties (Zagreb, Krapina-Zagorje, Sisak-Moslavina, Karlovac, Varazdin, Koprivnica-Krizevci, Bjelovar-Bilogora, Primorje-Gorski Kotar, Lika-Senj, ViroviticaPodravina, Pozega-Slavonija, Brod-Posavina, Zadar, Osijek-Baranja, Sibenik-Knin, Vukovar-Sirmium, Split-Dalmatia, Istria, Dubrovnik-Neretva, and Medimurje) in the period 2011-2016 was examined by the methodology of DEA. Therefore, estimate empirical efficiency scores of the decision-making units (DMU), in this case counties, two inputs and two outputs were applied. The input model included the variables of average expenditures for tourism and average expenditures for recreation, culture and religion, while the output model included total tourist arrivals and total tourist nights for each county in the 2011-2016 period. The data for input variables were collected from the official budgets of each county published on the websites of the Ministry of Finance of the Republic of Croatia and, for output variables, the data were collected from the Croatian Bureau of Statistics. The efficiency scores of the input and output variables for the average values in the 2011-2016 period were calculated by applying MaxDEA software, Version 7. Moreover, we calculated scale efficiency (SE) to identify which DMUs, in this case counties, operate at maximum scale or not.

In 1957 the foundations of the DEA model were laid by Farnell, which was later extended by Charnes et al. (1978). This is a non-parametric linear programming method for assessing the efficiency and productivity of DMUs. Moreover, this model identifies the most efficient units in a given set, without assuming any type of functional relationship between inputs and outputs. If both the input-oriented optimal solution and the outputoriented optimal solution exceed the value of one, the DMU is efficient.

Therefore, the efficiency curves created units that are relatively efficient compared to other observed units, by maximizing their output variables with specified input variables. Units that are included in data processing are considered relatively inefficient compared to other units that were excluded. Excluded units form an efficiency curve or marginal production function. The efficiency curve (frontier) is composed of units that utilize resources in the best possible way in order to achieve outputs. This curve also represents the goal the inefficient units are seeking to attain. Inefficient units may achieve their efficiency by representing their input and output values on the curve. Figure 1 presents the efficiency frontier of an input-oriented model. 
Figure 1: Efficient unit

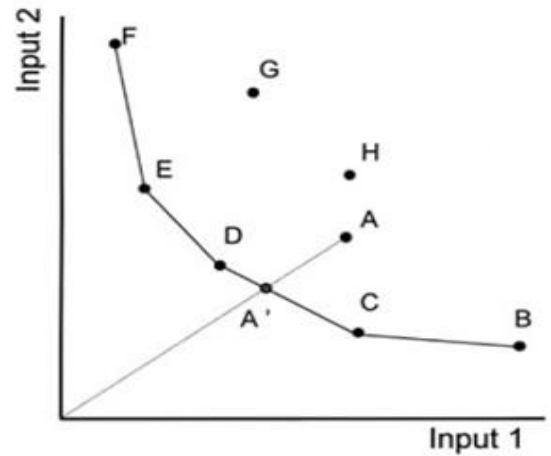

Source: Zhu (2002).

Based on the basic model of Charnes et al. (1978), two models were later developed The Charnes-Cooper-Rhodes (CCR) model (abbreviated as CRS) and Banker-CharnesCooper (BCC) model (abbreviated as VRS). For the purpose of conducting this research and exploring the efficiency of regional government expenditures, an input-oriented model was employed in this paper.

\subsection{CCR Model}

The CCR (abbreviated as CRS) model implies constant returns-to-scale, which means that output variables increase proportionally with input variables (Cooper et al., 2006). This model is specified in the following way:

$$
\max \theta_{0}=\frac{\sum_{r=1}^{s} u_{r} y_{r 0}}{\sum_{i=1}^{m} v_{i} x_{i 0}}
$$

Subject to:

$$
\begin{gathered}
\frac{\sum_{r=1}^{s} u_{r} y_{r j}}{\sum_{i=1}^{m} v_{i} x_{i j}} \leq 1 \quad(j=1,2, \ldots, n) \\
u_{1}, u_{2}, \ldots, u_{s} \geq 0 ; v_{1}, v_{2}, \ldots, v_{m} \geq 0 \\
u_{1}, u_{2}, \ldots, u_{s} \geq 0 ; v_{1}, v_{2}, \ldots, v_{m} \geq 0
\end{gathered}
$$


ToSEE - Tourism in Southern and Eastern Europe, Vol. 5, pp. 307-318, 2019

S. Hodžić, D. Jurlina Alibegović: THE EFFICIENCY OF REGIONAL GOVERNMENT EXPENDITURE ...

The above constraints specify that the ratio of output to input should not exceed 1 for each DMU. Furthermore, the objective is to achieve assigned weights by which the ratio is maximized for the particular DMU that is being analyzed. Because of the setup of the actual constraints, the optimal value is 1 .

\subsection{BCC Model}

The BCC (abbreviated as VRS) model assumes increasing returns-to-scale. Unlike the CCR model, which is represented by a straight line, the BCC model is represented by a convex efficiency frontier.

The model is specified in the following way:

$$
\max h_{k}=\sum_{r=1}^{s} u_{r} y_{r k}+u_{*}
$$

Subject to:

$$
\sum_{i=1}^{m} v_{i} x_{i k}=1
$$

The most important step in the formulation of a DEA model is the selection of input and output variables, because it could significantly improve the quality of the results in subsequent steps.

In addition, to determine which counties operate at maximum score or not, scale efficiency has been calculated. Scale efficiency for each county is determined as follows:

$$
S E=\frac{T E_{C R S}}{T E_{V R S}}
$$

Where:

TE $E_{C R S}$ is the technical efficiency of a county under constant returns-to-scale; and TEVRS is the technical efficiency of a county under variable returns-to-scale.

If the value of $\mathrm{SE}=1$, then the county is scale efficient, meaning that it operates at maximum scale.

\section{RESULTS}

The descriptive statistics for all input and output variables used in the DEA model are presented in Table 2. 
ToSEE - Tourism in Southern and Eastern Europe, Vol. 5, pp. 307-318, 2019 S. Hodžić, D. Jurlina Alibegović: THE EFFICIENCY OF REGIONAL GOVERNMENT EXPENDITURE ...

Table 2: Descriptive statistics on input/output data

\begin{tabular}{|l|c|c|c|c|}
\hline & Mean & St. Dev. & Min & Max \\
\hline $\begin{array}{l}\text { Expenditures } \\
\text { for tourism }\end{array}$ & 1268.161 & 1046.084 & 20.98333 & 3469.39 \\
\hline $\begin{array}{l}\text { Expenditures } \\
\text { for recreation, } \\
\text { culture and } \\
\text { religion }\end{array}$ & 7657.012 & 7057.484 & 776.3303 & 24670.18 \\
\hline Tourist arrivals & 603150.4 & 942133.7 & 10032.17 & 3175616 \\
\hline Tourist nights & 3282.618 & 5656.582 & 23.38467 & 20343 \\
\hline
\end{tabular}

Source: Authors' calculation.

Based on the average values of regional government expenditures for tourism and recreation, culture and religion as input variables and tourist arrivals and tourist nights as output variables, the DEA analysis in the form of an input-oriented model provided interesting results. The results are presented in Table 3.

Table 3: Efficient scores

\begin{tabular}{|c|l|l|}
\hline & CRS & VRS \\
\hline Bjelovar-Bilogora & 0.012 & 0.362 \\
\hline Brod-Posavina & 0.016 & 0.376 \\
\hline Dubrovnik-Neretva & 0.679 & $\mathbf{1 . 0 0 0}$ \\
\hline Istria & 0.622 & $\mathbf{1 . 0 0 0}$ \\
\hline Karlovac & 0.129 & 0.263 \\
\hline Koprivnica-Krizevci & 0.010 & 0.220 \\
\hline Krapina-Zagorje & 0.049 & 0.220 \\
\hline Lika-Senj & $\mathbf{1 . 0 0 0}$ & $\mathbf{1 . 0 0 0}$ \\
\hline Medimurje & 0.019 & 0.191 \\
\hline Osijek-Baranja & 0.007 & 0.048 \\
\hline Pozega-Slavonija & 0.030 & $\mathbf{1 . 0 0 0}$ \\
\hline Primorje-Gorski Kotar & 0.384 & 0.670 \\
\hline Sibenik-Knin & 0.722 & 0.991 \\
\hline Sisak-Moslavina & 0.018 & 0.221 \\
\hline Split-Dalmatia & 0.458 & 0.750 \\
\hline Varazdin & 0.080 & 0.705 \\
\hline Virovitica-Podravina & 0.008 & 0.283 \\
\hline Vukovar-Sirmium & 0.024 & 0.248 \\
\hline Zadar & 0.416 & 0.619 \\
\hline Zagreb & 0.012 & 0.090 \\
\hline
\end{tabular}

Source: Authors' calculation. 
ToSEE - Tourism in Southern and Eastern Europe, Vol. 5, pp. 307-318, 2019

S. Hodžić, D. Jurlina Alibegović: THE EFFICIENCY OF REGIONAL GOVERNMENT EXPENDITURE ...

Based on the observed results of the CRS or CCR model in the 2011-2016 period, only one county is efficient or only one county's value exceeds one, and this is Lika-Senj. The counties Sibenik-Knin and Dubrovnik-Neretva are also efficient, but not as efficient as Lika-Senj county. This means that output variables (tourist arrivals and tourist nights) increase proportionally with input variables. In a VRS or BCC model the most efficient counties are once again Lika-Senj, as well as Dubrovnik-Neretva, Istria, and PozegaSlavonija. In this model, we have more efficient counties where scores indicate variable returns-to-scale. This highlights an interesting fact, namely that counties in inland Croatia and along the coast were equally efficient over the observed period. Lika-Senj county is partially inland, partially coastal, Pozega-Slavonija county is inland, and Dubrovnik-Neretva and Istria are located along the coast. Hence, their regional government authorities recognized the importance of tourism for their regional development, especially in creating smart tourism destination. The results of scale efficiency are presented in Table 4.

Table 4: Scale efficiency results

\begin{tabular}{|l|c|c|}
\hline & Scale efficiency & RTS \\
\hline Bjelovar-Bilogora & 0.035 & Increasing \\
\hline Brod-Posavina & 0.044 & Increasing \\
\hline Dubrovnik-Neretva & 0.679 & Decreasing \\
\hline Istria & 0.622 & Decreasing \\
\hline Karlovac & 0.490 & Increasing \\
\hline Koprivnica-Krizevci & 0.049 & Increasing \\
\hline Krapina-Zagorje & 0.224 & Increasing \\
\hline Lika-Senj & 1.000 & Constant \\
\hline Medimurje & 0.103 & Increasing \\
\hline Osijek-Baranja & 0.156 & Increasing \\
\hline Pozega-Slavonija & 0.030 & Increasing \\
\hline Primorje-Gorski Kotar & 0.574 & Decreasing \\
\hline Sibenik-Knin & 0.728 & Decreasing \\
\hline Sisak-Moslavina & 0.082 & Increasing \\
\hline Split-Dalmatia & 0.610 & Decreasing \\
\hline Varazdin & 0.113 & Increasing \\
\hline Virovitica-Podravina & 0.029 & Increasing \\
\hline Vukovar-Sirmium & 0.096 & Increasing \\
\hline Zadar & 0.672 & Decreasing \\
\hline Zagreb & 0.138 & Increasing \\
\hline
\end{tabular}

Source: Authors' calculation. 
ToSEE - Tourism in Southern and Eastern Europe, Vol. 5, pp. 307-318, 2019

S. Hodžić, D. Jurlina Alibegović: THE EFFICIENCY OF REGIONAL GOVERNMENT EXPENDITURE ...

Based on the above results, we can conclude that only one county, Lika-Senj, is efficient. This indicates that the technical efficiency of a county is a comparative measure of how well it actually processes inputs to achieve its outputs, as compared to its maximum potential for doing so. On the other hand, scale efficiency takes two forms: decreasing returns-to-scale and increasing returns-to-scale. Decreasing returns-to-scale, or also known as diseconomies of scale, imply that a county is too large to take full advantage of scale efficiencies and has a supra-optimum scale size. Based on the observed results, six counties (Dubrovnik-Neretva, Istria, Primorje-Gorski Kotar, Sibenik-Knin, SplitDalmatia and Zadar) belong to a group of decreasing returns-to-scale, while all others (except Lika-Senj) belong to a group of increasing returns-to-scale. A county is scale efficient if it operates at constant returns-to-scale, which in our case is Lika-Senj county.

\section{CONCLUSION}

Every year, tourism plays a leading role in the service sector of the Croatian national economy. The tourism receipts in Croatia accounted for around 18 percent of the gross domestic product in 2016, which is high in comparison with other European Union countries. Besides this, current developments in technology have increased the core components and characteristics of smartness and smart tourism destinations. This concept of smartness and a smart tourism destination seems to be a great opportunity for long-term persistence and cross-sector cooperation. Moreover, governance aspects are central in the development of smart destinations.

In addition, regional and local governments have realized the importance and financial effect of tourism in their budget revenues and expenditures. Whereas in this paper the aim was to analyze the efficiency of regional government expenditures in 20 Croatian counties in the 2011-2016 period using the DEA mathematical model, the results of our empirical analysis provided an interesting result. In both models (CCR and BCC), there are prevailing inefficiencies in the way the Croatian regional governments use their financial resources. According to the results of scale efficiency, only Lika-Senj county is efficient with constant returns-to-scale. This is an interesting fact, since this county is partly within the Croatian interior, meaning that the tourists do not only come to enjoy the sea and sand. Since more and more tourists are changing their habits and behaviour, tourists are nowadays are more interested in enjoying nature and relaxing outdoors. By applying a DEA mathematical model, we only provide the result of technical efficiency, where Lika-Senj county was the most efficient, but to examine other aspects of efficiency, more detailed research is inevitable. Moreover, the regional government of that county recognized the importance of tourism as a way of keeping their budget sustainable. To increase regional and local government expenditure efficiency, our recommendation would be to organize better administrative and territorial organization of the country, to create smaller smart tourism destinations within the country, to promote them on international markets and to extend the concept of smartness to include other local government units, e.g. towns, cities and municipalities. For future research, we suggest introducing other input and output variables over a longer time period, based on available data, and comparing them with other local government units, not only in Croatia, but also abroad. 
ToSEE - Tourism in Southern and Eastern Europe, Vol. 5, pp. 307-318, 2019

S. Hodžić, D. Jurlina Alibegović: THE EFFICIENCY OF REGIONAL GOVERNMENT EXPENDITURE ...

\section{ACKNOWLEDGEMENTS}

This paper has been financially supported by the University of Rijeka, for the project ZP UNIRI 7/18.

\section{APPENDIX}

Table 1: Smart tourism destination characteristics

\begin{tabular}{|c|c|}
\hline Stakeholder & Characteristics of outcome \\
\hline Tourism organisations & $\begin{array}{l}\text { Function as smart hub } \\
\text { Digitization of core business processes } \\
\text { Engage with local communities, tourists and } \\
\text { the government in co-creating tourism } \\
\text { experience }\end{array}$ \\
\hline Governments & $\begin{array}{l}\text { Information governance that supports data } \\
\text { openness } \\
\text { Regulate data privacy } \\
\text { Establish public-private partnerships }\end{array}$ \\
\hline Local residents/local communities & $\begin{array}{l}\text { Constantly connected } \\
\text { Sufficiently creative and empowered } \\
\text { Actively involved in developing smart } \\
\text { heritage/e-Culture }\end{array}$ \\
\hline Tourists & $\begin{array}{l}\text { Well-connected and well-informed } \\
\text { Engaged both socially and technologically } \\
\text { Dynamically discuss issues via social media }\end{array}$ \\
\hline Environment & $\begin{array}{l}\text { Innovation ecosystem } \\
\text { Interconnected through Internet of Things } \\
\text { Sensor networks throughout the environment }\end{array}$ \\
\hline
\end{tabular}

Source: Buhalis and Amaranggana $(2014,560)$. 
ToSEE - Tourism in Southern and Eastern Europe, Vol. 5, pp. 307-318, 2019

S. Hodžić, D. Jurlina Alibegović: THE EFFICIENCY OF REGIONAL GOVERNMENT EXPENDITURE ...

\section{REFERENCES}

Albino, V., Berardi, U. and Dangelico, M. R. (2015), "Smart cities: Definitions, dimensions, performance and initiatives", Journal of Urban Technology, Vol. 22, No. 1, pp. 3-21, https:// doi.org/10.1080/10630732.2014.942092.

Afonso, A. and Aubyn, M. (2004), "Non-parametric Approaches to Education and Health Expenditure Efficiency in OECD Countries", Working paper, No. 5, School of Economics and Management, University of Lisbon.

Anderson, R.I., Fok, R. and Scott, J. (2000), "Hotel industry efficiency: An advanced linear programming examination", American Business Review, Vol. 18, No. 1, pp. 40-48.

Banker, R.D. and Morey, R.C. (1986), "Efficiency analysis for exogenously fixed inputs and outputs", Operations Research, Vol. 34, No. 4, pp. 513-521.

Barros, C.P. and Alves, F.P. (2004), "Productivity in tourism industry", International Advances in Economic Research, Vol. 10, No. 3, pp. 215-225.

Barros, C.P. and Mascarenhas, M.J. (2005), "Technical and allocative efficiency in a chain of small hotels", Hospitality Management, Vol. 24, No. 3, pp. 415-436.

Barros, C.P., Botti, L., Peypoch, N., Robinot, E., Solonandrasana, B. and Assaf, A.G. (2011), "Performance of French destinations: Tourism attraction perspectives", Tourism Management, Vol. 32, No. 1, pp. 141-146.

Bejakovic, P., Vuksic, G. and Bratic, V. (2011), "The Size of the Public Sector in Croatia", Croatian and Comparative Public Administration, Vol. 11, No. 1, pp. 99-125.

Boes, K., Buhalis, D. and Inversini, A. (2015), "Conceptualising smart tourism destination dimensions", in Xiang, Z. and Tussyadiah, I. (eds.), Information and communication technologies in tourism, Springer, Dublin, pp. 391-403.

Boes, K., Buhalis, D. and Inversini, A. (2016), "Smart tourism destinations: ecosystems for tourism destination competitiveness", International Journal of Tourism Cities, Vol. 2, No. 2, pp. 108-124 https//doi.org/ 10.1108/IJTC-12-2015-0032

Buhalis, D. and Law, R. (2008), "Progress in tourism management: Twenty years on and 10 years after the internet: The state of eTourism research", Tourism Management, Vol. 29, No. 4, pp. 609-663.

Buhalis, D. and Amaranggana, A. (2014), "Smart tourism destinations", in Xiang, Z. and Tussyadiah, I. (eds.), Information and communication technologies in tourism, Springer, Dublin, pp. 553-564

Charnes, A., Cooper, W.W. and Rhodes, E.L. (1978), "Measuring the efficiency of decision making units", European Journal of Operational Research, Vol. 3, No. 4, pp. 429-44.

Cooper, W.W., Seifrod, L.M. and Kaoru, T. (2006), Introduction to data envelopment analysis and its users, Springer, New York.

De Borger, L. and Naper, L.R. (2006), "Efficiency Potential and Efficiency Variation in Norwegian Lower Secondary Schools", Public Finance Analysis Vol. 62, No. 2, pp. 221-249.

Del Vecchio, P., Gioconda, M., Ndou, V. and Secundo, G. (2018), "Creating value from Social Big Data: Implications for Smart Tourism Destinations", Information Processing and Management, Vol. 54 pp. 847-860, https://doi.org/10.1016/j.ipm.2017.10.006

Hadad, S., Hadad, Y., Malul, M. and Rosenboim, M. (2012), "The economic efficiency of the tourism industry. A global comparison", Tourism Economics, Vol. 18, No. 5, pp. 931-940.

Hollands, R. G. (2008), "Will the real smart city please stand up?", City, Vol. 12, No.3, pp. 303-320.

Hodžić, S., Jurlina Alibegović, D. and Bečić, E. (2017), 'Efficiency of Public Expenditures: The Case of Croatian Counties", Proceedings of the 25th NISPACee Annual conference "Innovation Governance in the Public Sector", May 18-20, Kazan,, Russian Federation.

Hwang, S.-N. and Chang, T.-Y. (2003), "Using data envelopment analysis to measure hotel managerial efficiency change in Taiwan", Tourism Management, Vol. 24, No. 49, pp. 357-369.

Johns, N., Howcroft, B. and Drake, L. (1997), "The use of data envelopment analysis to monitor hotel productivity", Progress in Tourism and Hospitality Research, Vol. 3, No. 2, pp. 119-127.

Jurlina Alibegovic, D. and Blazevic, Lj. (2010), "Indexed of Efficiency and Management of the Local Development: Experence of the Reconstruction and Development Fund of the Town of Vukovar", Economic Review, Vol. 61, No. 11, pp. 631-665.

Jurlina Alibegovic, D. and Slijepcevic, S. (2012), "Identifying Key Obstacles for Performance Measurement at the Sub-National Level in Croatia", Croatian and Comparative Public Administration, Vol. 12, No. 4, pp. 1117-1156.

Mora, L. and Bolici, R. (2017), "How to Become a Smart City: Learning from Amsterdam", in Bisello, A., Vettorato, D., Richard, S., Elisei, P. (eds.), Smart and sustainable planning for cities and regions, Springer, Berlin, pp. 251-266. 
ToSEE - Tourism in Southern and Eastern Europe, Vol. 5, pp. 307-318, 2019

S. Hodžić, D. Jurlina Alibegović: THE EFFICIENCY OF REGIONAL GOVERNMENT EXPENDITURE ...

Neirotti, P., Raguseo, E. and Paolucci, E. (2016), "Are customers' reviews creating value in the hospitality industry? Exploring the moderating effects of market positioning", International Journal of Information Management, Vol. 36, No. 6, pp. 1133-1143.

O'Sullivan, A. and Sheffrin, S.M. (2003), Economics: Principles in Action. Prentice Hall, Upper Saddle River

Peypoch, N. (2007), "On measuring tourism productivity", Asia Pacific Journal of Tourism Research, Vol. 12 No. 3, pp. 237-244.

Sigala, M., Christou, E. and Gretzel, U. (2012), Web2.0 in travel, tourism and hospitality. Theory, practice and cases. Ashgate Publishers.

Shapiro, J.M. (2006), "Smart cities: Quality of life, productivity, and the growth effects of human capital", The Review of Economics and Statistics, Vol. 88, No. 2., pp. 324-335.

Soysal-Kurt, H. (2017), "Measuring Tourism Efficiency of European Countries by Using Data Envelopment Analysis", European Scientific Journal, Vol. 13, No. 10, pp. 31-49.

Zhu, J. (2002), Quantitative Models for Performance Evaluation and Benchmarking: Data Envelopment Analysis with Spreadsheets and DEA Excel Solver. Kluwer Academic Publishers, Netherlands.

Sabina Hodžić, PhD, Assistant Professor

University or Rijeka, Faculty of Tourism and Hospitality Management

Department for Public Finance

Primorska 42, 51410 Opatija, Croatia

Phone: + 385-51-294687

E-mail: sabinah@fthm.hr

Dubravka Jurlina Alibegović, PhD, Senior Research Fellow

Institute of Economics

Department for Local and Regional Development

Trg J.F. Kennedyja 7, 10000 Zagreb, Croatia

Phone: + 386-1-2362200

E-mail: djurlina@eizg.hr 